\title{
"The Extent of the Link between the Hegemony of the Major Powers Scientifically and Economically and Novel Coronavirus Spread"-A Study within the Framework of the Public International Law
}

\author{
Essam El-Din Mohamed Ibrahim ${ }^{1}$, Moamr Rateeb Mohamed Abd-Elhafez ${ }^{2}$ \\ ${ }^{1}$ Department of Legal Sciences, Egyptian College of Technology, Sohag, Egypt \\ ${ }^{2}$ College of Law, Assiut University, Assiut, Egypt \\ Email: esam.esam974@yahoo.com
}

How to cite this paper: Essam Ibrahim and Abd-Elhafez, M.R.M. (2020) "The Extent of the Link between the Hegemony of the Major Powers Scientifically and Economically and Novel Coronavirus Spread"-A Study within the Framework of the Public International Law. Open Access Library Journal, 7: e6588. https://doi.org/10.4236/oalib.1106588

Received: July 6, 2020

Accepted: August 15, 2020

Published: August 18, 2020

Copyright $\odot 2020$ by author(s) and Open Access Library Inc.

This work is licensed under the Creative Commons Attribution International License (CC BY 4.0).

http://creativecommons.org/licenses/by/4.0/

\section{(c) (i) Open Access}

\begin{abstract}
The international community is now less concerned with military forces as much as science, especially biological sciences, which increase the chance of possessing a large scientific force whose effects, if exploited by the bad exploitation, is stronger and fiercer than many military wars. This is what we are currently dealing with on the international scene in light of coronavirus (COVID-19) spread. The researcher believes in this paper that the reason for this is the competition of the five major countries to acquire all the power sources that would help to dominate the world and the global economy. This threatens certainly the international security and peace. In this context, the researcher believes that a great benefit to the United States of America destroying China and its significantly growing economy.
\end{abstract}

\section{Subject Areas}

Law

\section{Keywords}

Security Study, Biological Warfare, Biological Weapons, International Competition, International Relations

\section{Introduction}

Biological warfare was not a recent one, but was used in ancient times. In their 
wars, the Romans poisoned rivers and water wells. Moreover the biological weapons were used in the modern era in World War I. They consist of toxic bacterial components or bacterial toxins and its danger relies on its speedy spread. The most dangerous biological weapon is anthrax. A biological weapon can be defined as the intended production of living organisms that cause diseases, whether they are viruses, bacteria, toxic substances, or toxins resulting from the biological processes of these organisms that cause disease to other living things, such as humans, animals, and plants. This disease may ultimately lead to death, depending on the type of weapon and its effect. The person making the biological weapon uses the microbe as it is without tampering with his characteristics or adding new features to it, or genetic engineering technology. Molecular biology and biotechnology may be applied to develop this virus, such as increasing the ability of infection or adding a new trait to its properties (for example) adding the gene responsible for botulin poisoning to the virus responsible for disease by previous techniques, which makes the biological weapon more deadly. It is worth considering that there is a big difference between conventional weapons and biological weapons. The most important of these differences is that conventional weapons need huge funds and highly arming technology, while the biological weapon is a largely inexpensive weapon, because it can be produced from just a bacterial farm and some suitable environments for their development in a very normal laboratory for microbiology. Also it does not need much experience in the manufacturing process, but it definitely needs experience and great care in the insurance process. This because these microbes are very dangerous on the manufacturer himself and those around him if he was inexperienced or any error occurred even if it was a simple error. Also, very large quantities of these weapons can be produced simply because one cell of a microbe is capable in only 24 hours under the appropriate conditions giving us billions of cells and colonies. Likewise, as we said earlier, it is possible to obtain a huge strategic stock of some kind of microbes due to the speed of their reproduction, which does not exceed hours, and this is simply the most important characteristic of this type of weapon. The accuracy of hitting the target by conventional weapons is very high, while the accuracy of hitting targets by biological weapon is interfered by many natural factors such as wind, rain, air movement and direction. All of this affects the delivery of the microbe to the desired location passively or positively (Ashour, 2005) [1], (Tullio and shamal Burger, 2003) [2], (Ahmed, 2018) [3].

From the above it is clear that the countries that can benefit from these sciences are the only ones who possess the scientific qualifications that enable them to reach their political, economic and scientific goals and domain these sciences and not others. This explains the competition of the major countries America, China, Russia, England and France and the constant pursuit of dominance these fields even if at the expense of others. The researcher believes that the United States of America can carry out these researches and studies in order 
to eliminate any international entity that possesses the scientific and economic capabilities that help in continuous development, for example the United States always seeks to destroy China, which is increasingly developing in various sciences, including space science. China, as a country, certainly has these types of weapons, but the researcher believes that possessing these weapons is likely to be a means of defense in case of a similar attack of the same kind on it from any other country. This forms an effective threat to the international peace and security.

There is a study in this framework in which the researcher believes that the human right to the environment is one of the innovated rights. This recent human attention is due to the overlap between environmental issues, human rights and public freedoms, and his awareness of the degree of dangers face the environment in which he lives. As well as the cause of these damages that threaten the environment is the human irrational use of energy resources and scientific and technological progress in all aspects of life, especially in the methods and means of fighting. So it was necessary to protect these resources because they represent a legacy for generations and a natural and historical heritage of all countries, and this study concluded several results, including (Ahmad, 2018) [3]:

- The term weapons of mass destruction are not limited to nuclear, chemical and biological, but extends to any other weapons produced in the future that have similar characteristics to these weapons in the destructive effects and the damaging results, and the use of these weapons results in environmental damage that is extremely dangerous and difficult to compensate.

- The right to a healthy environment is an individual and group right at the same time, it is an individual right on the basis that it fulfills the basic needs of the individual, and a group right on the basis that the healthy environment is a right for mankind, people and present and future generations. This right is an evolving right that is impossible to be identified except through the goals that aim protecting the environment and safeguarding the basic rights of people and the interests of future generations.

There are also previous studies in which the researcher believes that the international humanitarian law articles came from the beginning to put an end to the suffering caused by armed conflict. For this purpose, international humanitarian law defines both the legal methods for fighters and the strategies and means of wars, including weapons. Using the chemical and biological weapons is a taboo for centuries, but the use of toxic gases in World War I led to the first international treaty, the Geneva Protocol of 1925, which prohibited the use of suffocating or toxic gases or similar and bacterial methods in warfare. 1925 protocol is considered a milestone in international humanitarian law, and other legal instruments followed in the form of treaties adopted by the countries in 1972 and 1993. All these treaties and legal actions concluded that the nature of nuclear weapons through the terrifying size of the damage they cause and the impossibility of controlling the effects resulting from them in Time and space, and 
in addition to the threat they pose to the environment, future generations and the survival of humanity, it must be ensured that these weapons are never used again and must be removed by establishing a legally binding international treaty, and recommended that international efforts be continued to reach a complete and comprehensive prohibition of production and the use of nuclear weapons (Murad, 2017) [4].

It is also studies that see that the phenomenon of international competition is considered one of the aspects of international dealing, but is a predominant characteristic of most international dealings, especially in its economic aspect, and competition is a natural way in international relations due to the difference of interests and their opposition in many areas, despite the increasing interdependence between countries. However, the conflict of interests necessitates the domination of competition in international relations, and the US-China relations are the ideal model for studying international competition in many political, economic, ideological and even ways of life and values (Tawil, 2017) [5].

Also there is a study that sees that if the target is invisible and does not become aware of the five senses which are looking, smelling, hearing and tasting, then defending against it is very difficult, and this difficult target is the so-called biological materials and used as biological weapons that began to be used in recent wars. Armies began in many countries preparing means to defend against these lethal weapons after the renewal became a reality during Desert Storm Operation and beyond. And since this time the fighting forces began to find inventions to protect from them and advanced systems to estimate them and accurate methods for measuring them and microbiology has played an important role in this field. The researcher added that the biological warfare means consist of many bacteria, viruses, and toxins, and there is a great difficulty in classifying each of these substances as one group because they differ radically from each other in their morphological form, their chemical and bio properties, their different effects and their ability to infection. Some of the biological arms have temporal effect or after incubation time effect depending on the type of microbe (Zeinhom, 2005) [6].

Research objectives: The aim of the research is to demonstrate the non-peaceful use of biological sciences despite the existence of international conventions prohibiting this, and that there is a relationship between the international competition among the major countries, especially America and China, in the economic and scientific field and the spread of the new coronavirus (COVID-19).

The importance of the research: The importance of research lies in drawing the attention of the international community to the seriousness of the use of biological scientific progress in an irrational way that threatens international peace and security to achieve control and domination of economic forces globally, and also the importance of the study is to draw attention to the need for competition between countries to be far away from the use of biological weapons. 
The limits of the research: The research is limited to studying biological weapons and their development, the extent of the relationship between them and the international competition, and its relationship to the spread of the new coronavirus (COVID-19).

Research problem: The research problem is represented in the question that "Is there a relation between the desire of the major powers to dominate the economic, scientific and biological forces and the possibility of a biological war in order to achieve that hegemony?"

"Is there a relationship between this desire and the spread of the new coronavirus (COVID-19)?"

Research methodology: The researcher adopted the analytical approach to the rules of international humanitarian law.

This research has yielded these results that:

1) The historical development of biological weapons has proven to be the easiest and least expensive way to control and kill other international powers.

2) The competition between countries, especially countries that possess scientific ability in the field of biological sciences, necessarily leads to a threat to international peace and security.

3) The United Nations, which took upon itself the task of maintaining international peace and security, especially in the area of the prohibition of the use of biological weapons, has failed in this task due to the dominance of the major powers and their overwhelming policies over the goals and principles of the United Nations.

4) The economic competition and the desire of the major powers to control the global economy may lead to the use of biological sciences in order to achieve this control even if it is at the expense of supporting international peace and security.

5) The new coronavirus (COVID-19) is a product of the scientific and economic competition between major countries, especially America and China, and perhaps the Huawei crisis between China and America is a good example of this.

\section{Biological Evolution and Silent Wars}

It can be said that the first use of biological weapons appeared during the First World War (1914-1918), as Germany established a secret program to infect horses and cattle owned by the Allied armies on the western and eastern banks with a virus affecting the gland. In addition to a German attempt in 1915 to spread the plague in San Petersburg to weaken the Russian resistance. Actually the real use of this type of weapon is due to the Middle Ages but is not developed, and historically we find that the plague (black epidemic) that killed about 25 million people, spread through the deliberate dumping of infected bodies by Tatar army p In the besieged city of Cava, which is now known as "Feodosia" in Ukraine now, then the disease was transmitted to the Mediterranean region by Italians fleeing "Cava", and from it spread throughout Europe during the 14th 
and 15th centuries, and many other incidents indicate the uses Various diseases and toxins during wars. For example, the bodies of the dead soldiers were transferred to the enemy lines in "Karlstein" in 1422, and a similar strategy was used using the bodies of plague victims in $1710 \mathrm{AD}$ during the battle between Russian and Swedish forces in Reval, and during the past two thousand years, Historical records registered the use of biological agents in the form of sick bodies, contaminated devices and animals (Al-Taaimat, 1996) [7].

\subsection{The First Topic: History of Inhuman Biological Weapons}

It can be said that biological weapons were part of the arsenals of ancient armies, and their first use dates back to the fourteenth century BC. These are some examples of biological attacks recorded by history. During the sixth century BC, the Assyrians poisoned the wells of the enemy with fungi that made them delirium. 300 years before birth quotes from Greek, Persian, and Roman literature referred to the use of dead animals to pollute wells and water sources, and in the 14th century (1346) and during the siege of Kava, a commercial site that belonged to the Republic of Genoa at the time and is located in the Crimea in Italy, the Tartars (the name comes from peoples For the Latter, and Europeans in the Middle Ages fired it on a part of Central and Northern Asia that extends from the Caspian Sea and the Ural Mountains to the Pacific Ocean), cast the bodies of the plague-infected people in the city to spread the epidemic at the enemy, and this was one of their most deadly and simpler weapons. This technique was also used in 1422 by the Lithuanian army, which besieged the city of Karolstein in Bohemia (Hani, 2017) [8], (Tullio and Shamal Burger, 2003) [2].

The history of biological wars can be listed as follows:

\subsection{The First Quest: Smallpox Epidemic}

At present, smallpox has been eradicated worldwide, but there is concern that terrorists may spread new variants, British settlers spread the epidemic of smallpox among the population of India in the 18th century. Returning to the First World War, we find traces of biological attacks using bacillus (a disease affecting hoofs) in an attempt to contaminate horses by France and Germany. Later, during World War II, Japan experimented for the first time biological warfare in Manchuria (China). In 1984, the world witnessed the first case of so-called bioterrorism, during which time the Rajnich community, in the state of Oregon (USA) contaminated the food of many restaurants in Dallas, Salmonella. 751 people were injured and the other 45 were transferred to the hospital. (Hani, 2017) [8], (Arnold, 2002) [9].

\subsection{The Second Quest: Ebola Virus}

The known Ebola virus disease, which was known as Ebola hemorrhagic fever, is a severe disease that affects humans as it is fatal, with the death rate caused by the Ebola virus, which falls within the filamentous family of viruses, to about 
$90 \%$. The Ebola virus was first recognized in 1976 when two outbreaks occurred simultaneously, one in Yambuku, a village not far from the Ebola river in the Democratic Republic of the Congo, and the other in a remote area in Sudan, symptoms of Ebola vary, but usually the patient at the beginning of the disease ("dry phase") suffers from the onset Sudden fever, severe debility, muscle aches, headache and sore throat. However, with the development of the disease, people with vomiting and diarrhea (the "wet phase"), rashes, and poor kidney and liver functions appear, usually in internal and external cases (WHO site, 2015) [10].

In 1992, members of the "Om Shinrikyo" group were accused for going to Zaire to obtain samples of the "Ebola" virus for using as a biological weapon. It appears that most of the time, biological weapons were used in armed conflicts, since an army is completely healthy without any disease can be guaranteed to win. In the $2007 \mathrm{AD}$, traces of what are believed to be the oldest attempts at biological attacks were found in the fourteenth century B.C. When the Hittites, returned their origins to Anatolia-present-day Turkey at that time the Hittites were weakened by Epidemic (tularemia) or rabbit fever, which is a bacterial infection transferring to humans. The Hittite neighbors, the Cedars, tried to conquer them after they realized their weakness. studies, conducted by Igno Trevisanato, indicated that the Hittites left the rams in nature hoping that the Cedars would in turn catch the germ and push them to abandon the invasion, but this strategy cost them a lot (Hani, 2017) [8].

From the previous narration, it is clear that the use of biological weapons denotes the immoral dimension in interactions between countries. Banning their use came after an agreement signed in 1972 whereby biological and chemical weapons that were identified at that time as actually poisonous weapons and immoral. Wars are no longer just a confrontation between two armies but it is enough to send a deadly virus to stir terror, panic and terrorism. Despite the presence of more than 1200 biological agents that can be used to spread diseases, only a relatively small number of them possess the characteristics that make it an ideal weapon to be used in wars. Al that encouraged the international community to set controls over the use of biological sciences and this is what we will talk about in the second topic.

\subsection{The Second Topic: Conventions and Protocols for Biological Warfare}

Biological weapons (biological or bacteriological) is a military term that means all means and causes that are used to spread infectious and deadly diseases among enemy forces in order to affect their combat efficiency and thus easing their defeat and end the battle. There is no doubt that the rapid progress in the field of scientific research In general and of genetic engineering in particular was the result of creating new properties and specifications for pathogens coinciding with a clear deficiency of preventive medicine ability to catch up with these developments. Although the human body has an immune system that works on 
two paths, the first is defense cells that attack and destroy germs and invading viruses and the second is the body's ability to produce antibodies that eliminate these pathogens, but the intensity and strength of these germs and viruses and mixing them with each other in one weapon makes the body lose the battle often. In addition to that when some individuals become ill It helps to spread it through infection if they are not isolated in time. Since 1925 AD, the first classification of that war was "bacteriological methods in wars", but the modern classification of bacterial warfare included bacterial warfare in addition to other non-bacterial agents and all of them were called the Biological weapons (Atallah, 2008) [11].

The US Army Dictionary has defined the definition of biological weapons as follows (Tulio and Shamalburger, 2003) [2]:

Introduce living organisms with their toxic live antagonists, hormones that regulate the growth of plants to cause death, or injuries to humans, animals, or plants, or be a defense against those actions.

As for the annual bulletin of the American Army in 1956, it defined the biological weapons as:

"Military use of living organisms, or their toxic products to cause death, disability, or destruction for humans or their domestic animals and plants, and are not limited to the use of bacteria, but also include the use of other microorganisms, plants, and other forms of living such as insects."

From this, we can say that biological weapons are one of the weapons of mass destruction, and are used to kill individuals and animals, infect crops, and infection occurs from biological weapons that include infectious microbes, and the toxins of these microbes.

Despite all these efforts, the danger of using biological weapons still exists, and the major countries still exchange accusations about conducting tests and development of biological weapons, and the researcher believes that the exchange of accusations supports this view that indicates that the major countries are not committed to the International agreements in this regard, but it always seeks to develop in order to destroy the other so as to ensure growth and economic and scientific control globally. There is no doubt that it is difficult to control the proliferation of biological weapons due to the ease of their development. This increases the difficulty of biological disarmament globally and increases the chances of being used in any conflict (Atallah, 2007) [12].

In this context, the researcher actually believes that despite calls and efforts for banning the biological weapons use issued by the United Nations, especially from its general organ, the General Assembly, as has already been said, the domination of the five major known countries-America, China, Russia, England and France-over the United Nations organization obstruct this great organization mission which is to maintain international peace and security and support various human rights, through the right of veto made by the five major countries to serve their political interests. This right in turn requires nothing but objection 
from one of these countries to any decision that could affect its economic and scientific development, even at the expense of international security and toxicity. All this makes efforts to ban biological weapons a mere ink on paper that does not resonate on the ground, and that is what we are dealing with in light of the spread of the new coronavirus and what It is left behind by international terrorism. The researcher believes the current situation that the world witness will not deviate from the dishonorable competition between America and China, where each seeks to develop its scientific and biological development in order to catch the other and achieve its collapse. Due to the increasing progress of China in various sciences and its control over the global economy, it is in America's interest to destroy China. This was clear in the Huawei company crisis, as US President Donald Trump sparked a new escalation in the strained economic relations with China, by announcing Google International and suspending its business with the Chinese telecom giant Huawei, in a move that would hinder the activities of the Chinese company in foreign markets. Alphabet corporation, the owner of Google, said that stopping any cooperation between it and Huawei requires any transfer of spare parts or programs except for those that are open source, and this resulted in depriving the Chinese company of some Android operating system updates and loss the possibility of access the Google App Store. Later US Department of Commerce imposed regulations to prevent Huawei Technology and 70 of its subsidiaries, their so-called "entity list", from obtaining components and technology from any American company without prior approval from the government. According to the Chinese newspaper "China Times"', the move may disrupt the work of Huawei outside China.

\section{The International Competition Phenomenon between the Major Countries and Its Relationship to the Novel Coronavirus Spread}

One of the quests of the research is to discuss the international competition phenomenon in an attempt to understand the changes that may lead to a cold war on the international scene and that could lead to the transformation of international relations from an ideological conflict to an open international competition in which the economy is the main factor. Accordingly we divide this chapter to the following investigations:

\subsection{The First Topic: The Concept of International Competition}

The competition phenomenon is a natural human case that arises as a result of individuals or groups seeking to achieve their interests and goals based on their available capabilities. These interests and goals are usually similar for everyone in the form of a peaceful race relationship, but whenever one of the parties tries to exaggerate these interests and keep them to himself and prevent others from getting it, this constitutes a reason to bring tension that can take the competition out of its peaceful scope and turn into violent conflict. This is almost the case 
regarding a competition whose parties are states or international actors, whatever their characteristic or weight on international peace (Tawil, 2017) [5].

\subsection{The First Quest: The Concept of International Competition}

Some prefer, in their interpretation of the international competition concept, to focus on the economic side, as it is the item of economical deep roots rather than other terms, deprived from it later such as free economical competition and international competition and others, as it moved from the field of economic sciences to the field of political science and specifically within economics studies, the political and international economic relations. The transformations that happened after the Cold War world which caused a continuous growth of the economic factor had a profound impact on the increasing importance of the phenomenon, as the economy became the most important and driving factor for the countries' foreign policies. This has created an atmosphere of economic competition with diplomatic mechanisms supported by technology and culture.

By studying the international competition phenomenon, a general trend has emerged in studies of international relations. Its supporters do not see a need to differentiate between the concepts of conflict and international competition, as there are thin borders that separate each of them. Therefore Conflict and competition for more power is the essence of relations between countries, but the mechanisms through which this conflict is managed are changing with time and space. These mechanisms have evolved from the ideological and race to arms and nuclear deterrence in the Cold War period to the mechanisms of purely economic, cultural and technological aspects after the end of this certified war at the level of international bodies and organizations, multinational corporations, deprived from various pretexts such as human rights and the war on terrorism (Mehrez, 2003) [13].

\subsubsection{The Linguistic Concept of International Competition}

The word "competition" in the Arabic language is known as race, which is an innate instinct that encourage doing effort to excel. On the other hand, it carries a meaning of precious value something, which pushes individuals or groups to race and compete with the aim of achieving this value, as mentioned in the Holy Qur'an verse 26 of Surat Al-Mutaffifin in the words of God Almighty addressing people urging them to do effort and noble race to obtain the good reward. Race in good deeds is the source of benefit and the source of progress in society according to the Quranic meaning of competition (Al-Munajjid, 1984) [14], (Al-Waseet, 1960) [15], (Abu Al-Azm, 2001) [16].

As for the term "international", it is a description derived from the name of the state, which means what is being circulated, so it is one time with a party and once with the other. It is called money and dominance. Using the term "international" emphasizes on the role of the state and its weight as a main doer in the international community. This term also derived from one of the law disciplines which deals with all issues that require legal judicial intervention, whose parties 
are the states or organizations that the states contributed to in establishing them, and from this the concept has evolved to include various other fields (Al-Waseet, 1960) [15].

\subsubsection{The Idiomatic Concept of International Competition (Muhammad, 2014) [17]}

Competition as a term is a process of interaction that accompanies the preparation of political decision-making, an activity by which two or more parties seek to achieve the same goal, and therefore competition varies in quantity and quality from one society to another and within the same society. This definition focuses on the fact that competition is centered around the interaction process associated with making the political decision, and the assumption that there are two or more parties with the same goal that they seek to achieve within societies or between states. But it remains an incomplete definition and does not cover its various aspects. And based on all the above, we can define international competition as: a situation that brings together two international parties or more according to rational consideration. Their effort concentrates on achieving the benefits and interests provided by a specific environment in the international system, without resorting to the use of military force and violence to collect these benefits and reach these goals.

Despite this, international competition, in the shadow of the post-Cold War world and the change in power factors that followed the emergence of the economic and technological factor in international relations, has increased. The international competition also increased with the growing phenomenon of cross-border globalization and the challenges it creates to penetrate the sovereignty of states through advanced technological means, and the emergence of supranational actors such as Multinationals whose sole goal is to maximize their benefits at the expense of local communities. All of this results in a scarcity of natural resources, especially oil, and, accordingly, international competition may take a dangerous turn and may develop into a stage of tension and conflict by non-competitive means, which is what, happens actually among the major powers in more than one region of the world.

\subsection{The Second Quest: International Competition and Similar Concepts}

The concept of international competition often overlaps with some other concepts through which it can be interpreted or managed, such as competitiveness, balance of power, conflict, tension, ... and others (Bouzidi, 2015) [18], (Mohamed, 1997) [19]. This is what we will see in the following presentation:

\subsubsection{Competitiveness and International Competition}

The concept of competition was transferred to the political field through the gateway of the economy and international economic relations, which occur between international parties, especially with the increasing phenomenon of interdependence and the increase in trade exchanges, and from it several concepts of 
competition developed. Competitiveness was the closest term which refers to, as the Political American Council agreed, "the ability of the country on producing goods and commodities which can compete in the global markets and at the same time achieve steady living standards in the long term". Therefore, the concept of competitiveness depends on countries and relevant international bodies to measure the countries progress degree and their ability to global economic competition. Despite the importance of the competitive indicators, they focus on one and only aspect of the phenomenon of broad international competition, while in reality the fields of international competition can extend to include aspects: military, scientific, technological, economic, commercial, cultural, information, etc., so the concept of competition remains part of the general concept of competition International.

\subsubsection{The Balance of Powers and Its Relationship to Competition}

The concept of balance of powers assumes the existence of a number of powers and counter powers centers or allies whose forces are balanced or nearly in order to deter any international center from exploiting any superiority in its powers to change the features of the existing international situation. Just as it was the international situation during the time of the bi-polarity (1945-1990) between the two camps communism and capitalism. The interactions that occurred between the units of the one camp fall within the framework of peaceful competition by virtue of a unified ideological rapprochement, while other interactions that occur between the political units of the two camps represent the summit of conflict. After the limitation of power balance situation based on the ideological dimension by the dissolution of the Soviet Union and the emergence of an international pluralism in the world, the power balance model based on alliances and ideological agreements has vanished. Also the influence of some traditional forces has been limited on the international scene with the emergence of other international powers, and the role of economic and technological factors that have become the subject of most international interactions and relations has grown later. This moved the concept of power balance After the Cold War, from its total dependence on the index of military strength to a balance of forces based on softer and more effective means at the lowest cost so technology advancement means a certain increase in power.

\subsubsection{Tension and Its Relationship to International Competition}

Tension is a state of anxiety and mutual distrust between two or more countries, and it may be a cause of international conflicts or even its result. It is also defined as "conflict situations that do not lead, at least temporarily, to use force". Tension is often the result of an accident or a situation taken as an excuse in which the interests and goals of the conflicting parties appear clearly. Despite the continus tries of hiding this tension through the different stages of the normal competition by the diplomatic political peaceful ways, tension increases according to the increase of the strategic, economic and political gains which a certain 
environment provide, especially with scarcity of resources and opportunities for influence areas for some forces and the decrease of the domination areas for some powers. Moreover the dominance of some powers with most of these gains in the shadows of the unfair distribution of them produces an increase in the degree of competition and from it increases the possibilities of anxiety and dissatisfaction that accompany the disappointment of countries affected by this competition and gets tension as a successive stage in the broader conflict phenomenon (Youssef, 1995) [20].

\subsubsection{International Conflict and Its Relationship to International Competition}

Conflict can be defined as a competition for power, values, and resources, whose goal is to harm, ruin, or neutralize opponents, and some thinkers and writers often try to combine the concepts of conflict and competition in the field of international relations, but it can be said that competition as a state is a phenomenon of conflict that may often start from Peaceful, nonviolent competition over issues and interests that are not characterized by contradictions in the fields of trade, technology, and economics, and may gradually develop with scarcity of resources, conflict of goals, complexity, and entanglement of interests into tension, crisis and conflict with the possibility of war, and vice versa, given that there was a shift in the function of international conflict after the end The cold war, from military action to epistemic economic and technological competition. We can say that the fundamental difference between the concepts of conflict and international competition appears mainly in the pattern of force used, since international relations during the Cold War were based on the ideological conflict between the Communist camp and the capitalist the two polar camps that dominated at the time. The military force was at the option and used between the parties to the conflict, although it never led to a direct armed confrontation between the two dominant powers. With the radical change that affected the international system after the dissolution of the Soviet Union, it moved International relations towards a new era, characterized in most of its stations by economic and technological competition between global powers for economic and political gains and areas of strategic influence by peaceful non-military means more than ever, especially after the growing need for scarce resources (oil, gas, minerals, water ...), and the Gulf region is considered The best evidence for this modern style of international competition (Qaderi, 2007) [21], (Abu Amer, 2004) [22].

\subsection{The Second Topic: Interpretation of the Phenomenon of International Competition in the Field of International Relations}

There is no doubt that competition in international relations is an ancient phenomenon between peoples and nations, as countries seek to achieve their interests with different motives in an atmosphere of inequality, chaos, and the ab- 
sence of a global authority above nationalism. Relying in this on the possibilities and capabilities that constitute their strengths and superiorities, as power is the necessary indicator that guarantees countries to wager any bet and win international competition. It can be said that nothing other than interest determines the external direction of states, as the idea of conflict for interests is in fact the essence of politics and its core. International and foreign policy is only two different sides of one phenomenon that is the struggle for power, i.e., authority and domination. Therefore the phenomenon of conflict in order to gain and develop more power, obtain and maximize interest and benefit, gain and preserve global dominance and leadership, in a world whose main advantage is chaos and instability, is the origin and natural state in international relations due to the absence of a centralized organized authority for this International relations. We believe that this is the closest conception of international relations from a realistic point of view, and when focusing on the phenomenon of conflict as a natural case in international relations according to the realistic perspective in its various old and new directions does not mean that it is an equal expression to the phenomenon of international competition but associated with them (Bouzidi, 2015) [18], (Twail, 2017) [5].

\section{The Extent of the Relationship between the Competition of the Five Major Countries and the Spread of the New Coronavirus (COVID-19)}

On the basis of the aforementioned talk about international competition and its interpretation as an international phenomenon, it led me to say that competition with the previous perception may include competition in the field of biological sciences in order to control the fundamentals of the global economy, and that the major countries among them may resort to biological struggle to ruin some countries that possess economic, military and scientific factors, and this interpretation can find interpretation in the relationship between China and America, as America always seeks to ruin China as it, in my opinion, controls the world economy (Tawil, 2017) [5].

Accordingly, the researcher believes that the economic, scientific and technological competition between the major countries, especially between America and China, may lead to a biological warfare that has a negative impact on international peace and security. From this point of view, the researcher believes we can say that the reason for the spread of the new coronavirus (COVID-19) is competition between the major countries especially America and China, and this can be explained through the following topic.

The First Topic: The Huawei Crisis between America and China Is an Introduction to a Long Cold War

It is known that there is an intense competition between China and the United States of America, especially in technological industries, which each country is 
trying to take over global markets individually. Regardless of the fact that the two countries are trying to become the largest economic country in this planet, but technically, this problem has started for more than a year, and this came as a result of the tremendous developments shown by Chinese products, especially technical companies and communication systems (Tawil, 2017) [5]. Huawei was able to reserve a leading place among the most advanced mobile phone companies, and was able to transform a large group of users from using the American Apple cell phones companies and the Korean Samsung. This point is what forced The American President to find alternative plans to stop the Chinese monster, and he was able to find claims that discredit the Chinese company such as accusations of espionage, And the arrest of the Huawei founder daughter in Canada on charges of financial fraud and tax evasion. But such trivial matters would not have hit Huawei in a killing spot so the United States searched for alternative ways to break the Chinese company's sailing, so US President Donald Trump found no way but ban dealing with the products of Huawei and its subsidiaries. Therefore the Chinese giant Huawei Company warned of the consequences of this war on the future of the technology industry. "Everyone witnessed the devastating and significant impact on many companies, including Huawei of course, as a result of the trade war between Washington and Beijing" said kain ho the deputy president of the company. The Chinese telecom giant was subjected to extensive monitoring and audits in recent months due to security concerns, after US officials warned that it is the intention of the Chinese government to use Huawei products to spy on the Americans, in addition to New Zealand and Australia banning the import of Huawei equipment from the fifth generation networks, but the Chinese giant denied these accusations, and the tension escalated even further when Meng Wanzhou, the chief financial officer of Huawei, was arrested. In Canada, the actions against Huawei have become a key issue in the largest trade confrontation between the United States and China. US President Donald Trump then suggested reviewing the legal procedures if this would help in his pursuit of a trade deal with China. On the other hand, other executives, representing Chinese companies in Davos, are concerned about the impact of the trade conflict. The Chinese state-owned oil and gas company president, Sinopec Ning Gaoning, said that Chinese companies are likely to downgrade their foreign investment plans, and the Chinese have appeared confused very much at a time when they thought they were welcome to invest in another country, and now they realize that they are not welcome all the time. From the above, we can say that the cold war between America and China about Huawei is not an economic or technical war but rather much, it is a prelude to a long war In the coming years, so China threatened that it will response to the US sanctions, which it described as an attempt to restrict the international trade activity of the Chinese technology giant Huawei. A Chinese Foreign Ministry spokesman said that Beijing opposes all countries that impose unilateral sanctions on Chinese companies, and that it will respond. Moreover Beijing ac- 
cused President Trump of involvement in an industrial sabotage operation using country security as a cloak to resist foreign business and companies, and demanded that Washington stop these practices and create a better atmosphere instead for business cooperation (BBC site, 2019) [23].

The researcher believes that these conflicts have been represented as decisions with an economic dimension to intervene, according to economic analyzes, within the American-Chinese economic and scientific war, by Donald Trump signing a decision to ban US companies from using communications equipment made by companies believed to represent a threat to national security.

\section{Conclusion and Recommendations}

\subsection{Conclusion}

We discussed in this research the biological development and the history of inhuman biological weapons, which prompted the international community to conclude many agreements and protocols that restrict and prohibit the use of these weapons. We have witnessed the desire of major countries, especially America, to control the global economy that led to competition in the field of biological, technological and economic sciences. There is no doubt that what is happening on the international scene now from the spread of the novel coronavirus (COVID-19) is a result of economic and scientific competition between the major countries, as a means of collecting all sources of powers that qualify to dominate the world and the global economy, and I ended up with a set of results and recommendations that we mention in the following.

\subsection{Recommendations}

More effective international standards must be established to regulate fair competition between countries, especially the major ones, in a manner that leads to support for international peace and security and the well-being of peoples.

The United Nations must be freed from the domination of the political, economic and scientific ambitions of the major powers so that they can achieve international peace and security on the ground.

The United Nations conventions and protocols banning the use of biological weapons must be reviewed by making them more compulsory and powerful as a step to protect the international community from the misuse of biological science.

\section{Conflicts of Interest}

The authors declare no conflicts of interest regarding the publication of this paper.

\section{References}

[1] Ashour, M. (2005) Microbes and Biological Warfare. Ma'arif Al-Maarif, Alexandria.

[2] Tullio, et al. (2003) Towards Agreement on Security Concepts, Glossary of Disar- 
mament and Confidence-Building Terms. United Nations Institute for Disarmament Research, Geneva.

[3] Ahmed, A.-W. (2018) Weapons of Mass Destruction from the Perspective of International Environmental Law. Fifth Scientific Conference (Law and Environment), 7.

[4] Murad, S.E. (2017) Ban and Restrictions on Modern Weapons in the Framework of International Humanitarian Law. Journal of Human Rights Generation, No. 24, 8.

[5] Twail, N. (2017) The Phenomenon of International Competition in International Relations. Algerian Journal of Security and Development, No. 6, 10.

[6] Zeinhom, M. (2005) Microbes and Biological Warfare. The Knowledge Facility, Alexandria.

[7] Al-Taaimat, H. (1996) Weapons of Mass Destruction and Disarmament Treaties. Mu'ta Mughlo for Humanities, Sixth Issue, Mu'tah.

[8] Hani, M. (2017) Biological Weapons, an Unethical History in Warfare. Research at the Center for Gulf Studies Center.

http://www.alkhaleej.ae/supplements/page/600050d0-4775-4947-814a-5e76e3305e2 d

[9] Arnold, D. (2002 AD) Imperial Medicine and Local Societies, by Dr. Mustafa Ibrahim Fahmy. National Council for Culture and Literature, Kuwait.

[10] https://www.who.int/csr/disease/ebola/faq-ebola/ar

[11] Atallah, N. (2008 CE) The Law of War or International Humanitarian Law, Part One. Raslan Publishing House, Damascus.

[12] Atallah, N. (2007 AD) Internationally Banned Weapons-Bases and Mechanisms. Dar Raslan, Damascus.

[13] Mehrez, A. (2003) The Right to Legitimate Competition. Legal Books House, Cairo.

[14] Upholstered in Language and Media (1984 AD) On the Meaning of Competition. Dar Al-Mashreq, 27.

[15] Al-Waseet Dictionary (1960) Arabic Tongue, Definition and International Meaning. Arabic Language Academy, Cairo.

[16] Al-Azm, A. and Ghani, A. (2001) Richness, the Meaning of Competition, Morocco.

[17] Muhammad, H. (2014) The Phenomenon of International Competition in International Relations. Journal of the Arab Democratic Center. https://democraticac.de/?p=1775

[18] Bouzidi, A.-R. (2015) American-Russian Competition in the Middle East. University of Mohamed Khedr Algeria.

[19] Muhammad, M. (1997) The Concept of Conflict, a Study in Theoretical Origins, Causes and Types. Journal of Future Studies, No. 3, 36.

[20] Youssef, N. (1995) Theory in International Relations. Arab Book House, Beirut.

[21] Qaderi, H. (2007) International Conflicts, an Analytical Study. Khair Jalis Publishing, Algeria, 19.

[22] Abu Amer, A. (2004) International Relations. Al-Shorouq Publishing, Amman.

[23] http://www.bbc.comlarabic 